\title{
PENERAPAN MEDIA VIDEO BREAKING NEWS DI TELEVISI GUNA MENINGKATKAN KETERAMPILAN MENULIS TEKS EKSPLANASI PADA SISWA KELAS VIII SMP MUTIARA SINGARAJA
}

\author{
Abdul Rohman ${ }^{1}$, I Wayan Rasna ${ }^{2}$, Ida Ayu Made Darmayanti ${ }^{3}$ \\ Prodi Pendidikan Bahasa Indonesia, Jurusan Bahasa Sastra Indonesia \\ dan Daerah, Fakultas Bahasa dan Seni, Universitas Pendidikan Ganesha \\ Singaraja
}

e-mail :abdulrohman200196@gmail.com, Wayanrasna@gmail.com, dayudarmayanti1984@yahoo.com

\begin{abstract}
ABSTRAK
Penelitian tindakan kelas yang dilakukan di SMP Mutiara Singaraja ini bertujuan mengetahui (1) langkah-langkah pembelajaran menulis teks eksplanasi dengan menggunakan video breaking news pada siswa kelas VIII SMP Mutiara Singaraja, (2) hasil peningkatan kemampuan siswa menulis teks eksplanasi melalui video breaking news pada siswa kelas VIII SMP Mutiara Singaraja, dan (3) respons siswa terhadap penerapan media video breaking news dalam pembelajaran menulis teks eksplanasi di kelas VIII SMP Mutiara Singaraja. Penelitian ini menggunakan rancangan deskriptif kuantitatif dan kualitatif. Subjek penelitian ini adalah siswa dan guru bahasa Indonesia kelas VIII SMP Mutiara Singaraja. Objek penelitian ini adalah proses pembelajaran serta peningkatan kemampuan menulis teks eksplanasi melalui media video breaking news, dan respons siswa. Data dikumpulkan dengan metode observasi, tes, dan kuesioner. Hasil penelitian ini menunjukkan (1) proses pembelajaran terdiri dari beberapa langkah dan berjalan dengan baik sekaligus siswa aktif dalam melaksanakan kegiatan pembelajaran, (2) tercapainya ketuntasan hasil belajar menulis teks eksplanasi siswa, yakni pada siklus I memperoleh skor rata-rata $74,5 \%$, sedangkan pada siklus II nilai ratarata siswa meningkat menjadi $82,6 \%$, dan (3) respons siswa pada siklus I dan siklus II tergolong positif terhadap penggunaan media video breaking news untuk meningkatkan kemampuan dalam menulis teks eksplanasi. Rata-rata perolehan respons pada siklus I sebesar 41,46 dan pada siklus II sebesar 42,07. Dapat disimpulkan bahwa penerapan media video breaking news di televisi dapat meningkatkan keterampilan menulis teks eksplanasi pada siswa kelas VIII SMP Mutiara Singaraja.
\end{abstract}

Kata Kunci: video breaking news, menulis, teks eksplanasi.

\begin{abstract}
The classroom action research conducted at Singaraja Pearl Middle School aims to find out (1) the learning steps in writing explanatory texts using the breaking news video on class VIII Singaraja Pearl Middle School, (2) the results of students' ability to write explanatory texts through the breaking news video on VIII grade students at Singaraja Pearl Middle School, and (3) student responses to the application of breaking news video media in learning to write explanatory texts in class VIII of Singaraja Pearl Middle School. This study uses a quantitative and qualitative descriptive design. The subjects of this study were class VIII Indonesian language students and teachers at Singaraja Pearl Middle School. The object of this research is the learning process and the improvement in the ability to write explanatory texts through the media of breaking news videos and
\end{abstract}


student responses. Data was collected by observation, tests and questionnaires. The results of this study indicate (1) the learning process consists of several steps and runs well as well as active students in carrying out learning activities, (2) achievement of completeness of learning outcomes in writing explanatory text of students, ie in the first cycle obtained an average score of $74.5 \%$, while in the second cycle the average score of students increased to $82.6 \%$, and (3) the response of students in the first cycle and the second cycle was positive for the use of breaking news videos to improve their ability to write explanatory texts. The average response rate in the first cycle is 41.46 and in the second cycle is 42.07 . It can be concluded that the application of breaking news video media on television can improve explanatory text writing skills for class VIII students of Singaraja Pearl Middle School.

Keywords: breaking news video, writing, explanatory text.

\section{PENDAHULUAN}

Pada era globalisasi, masyarakat sering mengalami peningkatan, baik secara teknologi maupun pendidikan. Demi upaya pembaharuan dalam dunia pendidikan, media sangat penting guna mencapai tujuan pembelajaran yang menyenangkan. Menurut Arsyad (2010: 25), media yang sering diganti dengan kata mediator adalah penyebab atau alat bantu yang turut campur tangan dalam dua pihak dan mendamaikannya. Jadi, secara bahasa, media pembelajaran berarti pengantar pesan dari pengirim kepada penerima pesan dalam proses pembelajaran.

Media komunikasi telah memengaruhi banyak perilaku dan kegiatan manusia dalam kehidupan sehari-hari termasuk terhadap dunia pendidikan. Salah satu media yang sangat berpengaruh adalah media televisi. Menurut Sutisno (1993: 1), media televisi pada hakikatnya merupakan suatu sistem komunikasi yang menggunakan suatu rangkaian gambar elektronik yang dipancarkan secara cepat, berurutan, dan diiringi unsur audio. Oleh karena itu, televisi merupakan salah satu alat untuk memberikan informasi yang disampaikan melalui audio visual dan berlangsung satu arah. Chanel di televisi banyak hal yang ditayangkan seperti film kartun, ftv, ceramah agama, politik, budaya, senitron, berita, dan lain-lain. Dalam pembelajaran menulis teks eksplanasi, salah satu chanel di televisi yang dapat digunakan adalah breaking news (berita sela).

Berita menampilkan fakta, tetapi tidak setiap fakta merupakan berita. Berita biasanya menyangkut orang-orang, tetapi tidak setiap orang bisa dijadikan berita. Berita merupakan sejumlah peristiwa yang terjadi di dunia, tetapi hanya sebagian kecil saja yang dilaporkan. Untuk memperkuat penyajian di atas peristiwa yang sedang kita pantau dan cara menyajikannya, reporter pencari berita harus mempunyai definisi sendiri mengenai lingkup pekerjaannya.

Salah satu hal yang dipentingkan dalam penyusunan berita adalah keterampilan menulis. Menulis dapat dikatakan sebagai kegiatan yang produktif untuk menambah wawasan bagi penulis tersebut. Sejalan dengan pendapat itu, Tarigan (1994: 3) menyatakan bahwa menulis merupakan kegiatan produktif dan ekspresif. Dikatakan produktif karena menulis merupakan kegiatan yang aktif menghasilkan tulisan. Menulis dikatakan ekspresif karena dengan menulis seseorang dapat mengungkapkan gagasan, 
maksud pikiran, atau pesan yang dimilikinya kepada orang lain.

Kegiatan menulis menjadi kegiatan yang paling sulit dibandingkan kegiatan membaca, menyimak, dan berbicara dalam pembelajaran Bahasa dan Sastra Indonesia. Kesulitan itu terjadi karena kegiatan menulis melalui proses kritis untuk dapat mengungkapkan ide atau gagasan ke dalam sebuah tulisan. Tidak hanya mampu dalam menuangkan gagasan, ide, pikiran atau pesan ke dalam tulisan, tetapi penulis juga harus mampu membuat tulisannya dipahami oleh pembaca.

Berdasarkan Kurikulum 2013 tingkat SMP, pada mata pelajaran Bahasa Indonesia kelas VIII, terdapat beberapa jenis teks yang akan dipelajari oleh siswa, antara lain teks observasi, teks deskripsi, teks eksposisi, dan teks eksplanasi. Salah satu pembelajaran yang dapat melatih berpikir siswa dalam ranah keterampilan menulis pembelajaran Bahasa Indonesia adalah memproduksi teks eksplanasi. Menurut Prihantini (2015: 102), teks eksplanasi sering dipakai untuk karya ilmiah untuk menjelaskan proses terciptanya sesuatu yang terjadi secara ilmiah.

Melalui pembelajaran menulis teks eksplanasi, diharapkan siswa dapat berlatih dalam mengungkapkan pikirannya secara jernih, untuk menerangkan, atau menjelaskan serangkaian proses dari suatu peristiwa atau fenomena alam yang diketahuinya secara benar berdasarkan sebab dan akibat. Dengan begitu, kemampuan menulis siswa akan terlatih secara kritis dalam mencari pengetahuan dan fakta-fakta walaupun dianggap lebih rumit dari teks lain.

Berdasarkan hasil wawancara peneliti dengan Ibu $\mathrm{Ni}$ Luh Putu
Arthini, selaku guru mata pelajaran Bahasa Indonesia di kelas VIII SMP Mutiara Singaraja, peneliti mendapat informasi bahwa kemampuan menulis siswa dalam pembelajaran menulis teks eksplanasi masih tergolong cukup. Guru mengatakan bahwa skor rata-rata dari 34 siswa dalam menulis teks ekplanasi masih di bawah KKM, yakni 68,88 sedangkan KKM mata pelajaran Bahasa Indonesia adalah 70. Dari 34 orang siswa, yang mencapai KKM hanya 13 orang $38,23 \%$, sedangkan 21 orang $61,76 \%$ mendapatkan skor di bawah KKM. Hal ini membuktikan siswa dalam menulis teks eksplanasi masih mengalami kesulitan dalam memulai menulis teks eksplanasi yang sesuai dengan struktur penulisan. Selain itu, berdasarkan hasil observasi, rendahnya kemampuan siswa dalam menulis disebabkan oleh kurangnya minat belajar siswa dalam menulis, siswa kurang memperhatikan guru ketika guru sedang memberikan materi, ada beberapa siswa yang sibuk dengan kegiatannya sendiri, siswa juga terlihat kurang bersemangat mengikuti pembelajaran dan siswa kurang aktif bertanya ataupun menjawab ketika pembelajaran sedang berlangsung, siswa terlihat bosan mengikuti pembelajaran dikarenakan oleh metode yang digunakan oleh guru hanya itu-itu saja, minat siswa dalam mengikuti pembelajaran sangat kurang, siswa terlihat mengantuk ketika guru sedang memberikan pembelajaran, dan siswa merasa kesulitan dalam mengembangkan ide ataupun gagasan ketika diminta untuk menulis. Selain permasalahan tersebut, guru juga mengatakan bahwa guru sangat kurang dalam masalah teknologi dan guru kurang mengerti memilih media yang menarik ketika mengajar di dalam 
kelas. Berdasarkan hal tersebut, dapat disimpulkan bahwa skor menulis siswa SMP Mutiara Singaraja masih rendah.

Guru melakukan usaha-usaha untuk menumbuhkan motivasi agar siswanya melakukan aktivitas belajar dengan baik sehingga dalam pembelajaran menulis teks eksplanasi di SMP Mutiara Singaraja. Guru dapat menggunakan video breaking news sebagai media pembelajaran. Video yang digunakan adalah video yang bersumber dari televisi. Media pembelajaran yang dikembangkan dengan menggunakan video breaking news memiliki beberapa kelebihan dibandingkan dengan media yang lain, yaitu dapat menyajikan materi secara visual diikuti dengan penjelasan suara, lebih menarik, dan menyenangkan sehingga dapat menumbuhkan dan meningkatkan motivasi siswa dalam belajar. Dengan menggunakan video breaking news sebagai media pembelajaran, siswa dapat dengan mudah mengemukakan pendapat sehingga hasil belajar dalam menulis teks eksplanasi meningkat dan mencapai nilai standar KKM. Cara pembelajaran ini perlu diterapkan oleh guru di sekolah. Dengan demikian, peneliti ingin mengamati proses pembelajaran menulis teks eksplanasi SMP Mutiara Singaraja agar dapat menjadi pedoman alternatif dan anutan bagi sekolah lain.

\section{METODE PENELITIAN}

Penelitian ini dirancang dengan menggunakan penelitian tindakan kelas, yakni dengan pendekatan kualitatif dan kuantitatif. Dalam penelitian ini, peneliti menggunakan beberapa siklus untuk mencapai kriteria keberhasilan. Hal ini dikarenakan oleh bagian penting dari sebuah penelitian tindakan kelas adalah adanya tindakan nyata.

Dalam penelitian ini, yang menjadi subjek penelitian adalah siswa dan guru bahasa Indonesia kelas VIII SMP Mutiara Singaraja. Kemudian objek dalam penelitian ini adalah proses pembelajaran serta peningkatan kemampuan menulis teks eksplanasi melalui media video breaking news di televisi, dan respons siswa.

Pelaksanaan penelitian tindakan kelas (PTK) dilakukan secara bertahap dan multisiklus. Setiap siklus terdiri atas refleksi awal, rancangan tindakan, pelaksanaan tindakan, observasi/evaluasi, dan refleksi.

Setelah dilakukan multisiklus, tahap selanjutnya adalah rincian prosedur awal yaitu refleksi awal, perencanaan tindakan, pelaksanaan, observasi dan evaluasi, dan refleksi.

Dalam penelitian ini menggunakan beberapa pengumpulan data untuk menjawab rumusan masalah. Metode pengumpulan data yang digunakan dalam penelitian ini adalah metode observasi, metode tes, dan metode angket atau kuesioner. Metode observasi yang digunakan berupa observasi partisipasi pasif. Artinya, peneliti tidak ikut secara aktif dalam kegiatan belajar-mengajar, tetapi mengamati dan melakukan pencatatan terhadap pelaksaan pembelajaran dan situasi yang menyertainya. Catatan dilakukan pada lembar observasi yang telah disiapkan.

Selanjutnya adalah metode tes. Metode tes yang digunakan dalam pengumpulan data adalah tes unjuk kerja/praktik. Selain menggunakan metode observasi dan tes, dalam penelitian ini juga menggunakan metode 
kuesioner/angket.

$$
\text { Metode }
$$

kuesioner/angket ini berisi pertanyaan yang diajukan secara tertulis kepada responden (siswa).Dalam penelitian ini juga menggunakan teknik analisis data.

Untuk mengetahui tingkat kemampuan menulis teks eksplanasi pada siswa digunakan metode tes/unjuk kerja (praktik). Data ini dianalisis dengan teknik deskriptif kuantitatif dan deskriptif kualitatif.

Data berkaitan dengan
respons siswa
penggunaan media video breaking
news untuk meningkatkan kemampuan menulis teks eksplanasi. Dalam pembelajaran menulis teks eksplanasi akan dianalisis dengan menggunakan analisis data deskriptif kuantitatif dan deskriptif kualitatif. Setelah data respons siswa disampaikan dengan angka-angka tersebut, akan dibahas dengan menggunakan kata-kata sehingga diperoleh suatu simpulan yang pasti dan jelas. Penelitian mengenai respons siswa dianggap berhasil apabila jumlah siswa yang merespons posistif lebih banyak daripada jumlah siswa yang merespons negatif.

Kriteria keberhasilan yang digunakan sebagai patokan dalam mengakhiri penelitian ini adalah sebagai berikut. Yang pertama, Kriteria keberhasilan pelaksanaan tindakan (yang menggambarkan perbaikan kualitas pembelajaran) adalah apabila dalam proses pembelajaran, tindakan yang dilaksanakan sudah tercapai dengan baik.

$\begin{array}{crr}\text { Yang } & \text { kedua, } & \text { Standar } \\ \text { keterampilan } & \text { teks }\end{array}$ eksplanasi adalah 75\%, siswa mampu mendapat nilai $75-100$, yaitu sesuai dengan standar ketuntasan minimal di SMP Mutiara Singaraja. Dan yang ketiga, Kriteria respons siswa dikatakan baik apabila dalam mengikuti pembelajaran dengan menggunakan media video breaking news sebanyak $75 \%$ siswa menyatakan senang mengikuti pembelajaran terhadap media yang digunakan saat pembelajaran menulis teks eksplanasi.

\section{HASIL PENELITIAN}

Untuk memperoleh data penelitian yang relevan, penelitian ini menggunakan tiga instrumen penelitian, yaitu (1) pedoman observasi untuk mengetahui langkah-langkah pembelajaran menulis teks eksplanasi, (2) tes untuk mengetahui kemampuan atau hasil belajar siswa menulis teks eksplanasi, dan (3) kuesioner untuk mengetahui respons siswa terhadap penerapan media video breaking news di televisi dalam meningkatkan keterampilan menulis teks eksplanasi. Penelitian ini dilakukan di kelas VIII SMP Mutiara Singaraja. Peneliti melakukan pengamatan terhadap 1 (satu) orang guru Bahasa Indonesia yang mengajar di kelas VIII SMP Mutiara Singaraja. Pada bagian ini disajikan data yang diperoleh dan dikelompokkan sesuai dengan rumusan masalah dan metode yang digunakan sebagai berikut.

Pada refleksi awal, kegiatan atau aktivitas pembelajaran berupa umpan balik dari guru kepada peserta didik saat mengikuti proses belajar mengajar dalam kurun waktu tertentu. Penilaian difokuskan pada keterampilan menulis teks eksplanasi tanpa menggunakan media video breaking news. Adapun empat aspek yang akan dinilai, yaitu isi, struktur, penggunaan bahasa, dan pengembangan/pendeskripsian. Berdasarkan perolehan skor pada hasil tes siklus I, yakni berjumlah 1919 dengan rata-rata $73,8 \%$, 
terdapat peningkatan data awal terhadap pembelajaran menulis teks eksplanasi. Namun, peningkatan tersebut belum memenuhi standar ketuntasan yang telah ditetapkan oleh pihak sekolah, yakni 75. Pada siklus I ini belum mencapai nilai standar yang ditetapkan, yaitu 75 . Setelah pelaksanaan siklus I, hasil penugasan menulis teks eksplanasi dengan menggunakan media video breaking di televisi ternyata masih memiliki hambatan. Oleh karena itu, nantinya pada sisklus II perlu dilakukan perbaikan agar nilai yang diperoleh siswa meningkat.

Skor rata-rata pada hasil respons siswa siklus I, yakni berjumlah 1078 dengan rata-rata $41,46 \%$. Berdasarkan perolehan skor rata-rata respons siswa tersebut, respons siswa terhadap pembelajaran menulis teks eksplanasi dengan menggunakan media video breaking news masuk kategori positif karena mendapat nilai dengan rata-rata $41.46 \%$. Persentase siswa yang memiliki respons sangat positif, positif, cukup positif, kurang positif, dan sangat kurang positif akan diuraikan sebagai berikut.

Berdasarkan kuesioner yang dilakukan pada siswa, diketahui bahwa 5 siswa dengan persentase $19,37 \%$ memiliki respons sangat positif, 20 siswa dengan persentase $76,92 \%$ memiliki respons positif, 1 siswa dengan persentase 3,84\% memiliki respons cukup positif, dan tidak ada yang memiliki respons kurang positif dan sangat kurang positif. Dengan demikian, dapat dikatakan bahwa rata-rata respons siswa terhadap penggunaan media video breaking news di televisi sebagai media utama untuk meningkatkan keterampilan menulis teks eksplanasi ini terbilang positif.
Pada siklus II, penugasan masih difokuskan pada keterampilan menulis teks eksplanasi siswa dengan menggunakan media video breaking news di televisi. Hasil menulis kemudian diproses oleh peneliti dan diberikan skor sesuai dengan tulisan siswa dari hasil penugasan.

Berdasarkan perolehan skor pada hasil tes siklus II, yakni berjumlah 2127 dengan rata-rata $81,8 \%$, terdapat perubahan nilai dari hasil siswa menulis teks eksplanasi. Terjadi peningkatan yang signifikan, hal ini terlihat dari jumlah keseluruhan skor dan rata-rata yang diperoleh antara siklus I dan siklus II. Jumlah nilai secara keseluruhan pada siklus I adalah 1919 dengan rata-rata $73,8 \%$, sedangkan pada siklus II mendapat total skor berjumlah 2127 dengan rata-rata $81,8 \%$. Itu berarti penggunaan media video breaking news dapat meningkatkan kemampuan menulis teks eksplanasi.

Untuk lebih jelasnya, berikut ini disajikan perbandingan skor menulis teks eksplanasi siswa kelas VIII SMP Mutiara Singaraja dengan bantuan media video breaking news. Perbandingan skor ini diambil dari hasil pratindakan, tindakan siklus I, dan tindakan siklus II

\section{Tabel 4.8}

Perbandingan Skor Pratindakan, Tindakan Siklus I, dan Tindakan

Siklus II

\begin{tabular}{|c|c|c|c|c|c|}
\hline \multirow[b]{2}{*}{$\begin{array}{l}\mathbf{N} \\
\mathbf{0}\end{array}$} & \multirow[b]{2}{*}{ Nama } & \multirow{2}{*}{$\begin{array}{l}\text { Nilai } \\
\text { awal }\end{array}$} & \multicolumn{2}{|c|}{ Siklus } & \multirow[b]{2}{*}{$\begin{array}{c}\text { Keteranga } \\
\mathbf{n}\end{array}$} \\
\hline & & & I & II & \\
\hline 1 & $\begin{array}{l}\text { I Ketut } \\
\text { Darma }\end{array}$ & 60 & $\begin{array}{l}7 \\
3\end{array}$ & $\begin{array}{l}7 \\
6\end{array}$ & meningkat \\
\hline 2 & $\begin{array}{l}\text { Adelia } \\
\text { Nur } \\
\text { Azizah }\end{array}$ & 70 & $\begin{array}{l}8 \\
0\end{array}$ & $\begin{array}{l}8 \\
4\end{array}$ & meningkat \\
\hline 3 & $\begin{array}{l}\text { Aldi } \\
\text { Maula } \\
\text { na }\end{array}$ & 65 & $\begin{array}{l}7 \\
2\end{array}$ & $\begin{array}{l}7 \\
5\end{array}$ & meningkat \\
\hline
\end{tabular}


e-Journal Jurusan Pendidikan Bahasa dan Sastra Indonesia

Volume : 9 Nomor: 2, Agustus 2019

P-ISSN : 2614-4743 (cetak) dan e-ISSN : 2614-2007 (online)

\begin{tabular}{|c|c|c|c|c|c|}
\hline 4 & $\begin{array}{l}\text { Faqih } \\
\text { Firma } \\
\mathrm{n} \\
\text { Hiday } \\
\text { at }\end{array}$ & 65 & $\begin{array}{l}7 \\
0\end{array}$ & $\begin{array}{l}8 \\
4\end{array}$ & meningkat \\
\hline 5 & $\begin{array}{l}\text { Gede } \\
\text { Andi } \\
\text { Putra }\end{array}$ & 66 & $\begin{array}{l}7 \\
0\end{array}$ & $\begin{array}{l}7 \\
5\end{array}$ & meningkat \\
\hline 6 & $\begin{array}{l}\text { Gede } \\
\text { Manda } \\
\text { Putra }\end{array}$ & 65 & $\begin{array}{l}7 \\
0\end{array}$ & $\begin{array}{l}7 \\
5\end{array}$ & meningkat \\
\hline 7 & $\begin{array}{l}\text { I } \\
\text { Koma } \\
\text { ng } \\
\text { Ngura } \\
\text { h } \\
\text { Winart } \\
\text { a }\end{array}$ & 72 & $\begin{array}{l}8 \\
2\end{array}$ & $\begin{array}{l}8 \\
3\end{array}$ & meningkat \\
\hline 8 & $\begin{array}{l}\text { I } \\
\text { Kadek } \\
\text { Yenta } \\
\text { Saputr } \\
\text { a }\end{array}$ & 65 & $\begin{array}{l}7 \\
0\end{array}$ & $\begin{array}{l}8 \\
5\end{array}$ & meningkat \\
\hline 9 & $\begin{array}{l}\text { Kadek } \\
\text { Adi } \\
\text { Darsa } \\
\text { na }\end{array}$ & 65 & $\begin{array}{l}7 \\
3\end{array}$ & $\begin{array}{l}7 \\
6\end{array}$ & meningkat \\
\hline $\begin{array}{l}1 \\
0\end{array}$ & $\begin{array}{l}\text { Kadek } \\
\text { Antoni } \\
\text { o }\end{array}$ & 65 & $\begin{array}{l}7 \\
0\end{array}$ & $\begin{array}{l}8 \\
5\end{array}$ & meningkat \\
\hline $\begin{array}{l}1 \\
1\end{array}$ & $\begin{array}{l}\text { Kadek } \\
\text { Sari } \\
\text { Jempir } \\
\text { ing }\end{array}$ & 65 & $\begin{array}{l}8 \\
2\end{array}$ & $\begin{array}{l}8 \\
3\end{array}$ & meningkat \\
\hline $\begin{array}{l}1 \\
2\end{array}$ & $\begin{array}{l}\text { Kadek } \\
\text { Listia } \\
\text { Suard } \\
\text { ani }\end{array}$ & 60 & $\begin{array}{l}7 \\
0\end{array}$ & $\begin{array}{l}8 \\
0\end{array}$ & meningkat \\
\hline $\begin{array}{l}1 \\
3\end{array}$ & $\begin{array}{l}\text { Ketut } \\
\text { Sarina } \\
\text { di }\end{array}$ & 80 & $\begin{array}{l}8 \\
8\end{array}$ & $\begin{array}{l}9 \\
0\end{array}$ & meningkat \\
\hline $\begin{array}{l}1 \\
4\end{array}$ & $\begin{array}{l}\text { KM } \\
\text { Kresn } \\
\text { a Adi } \\
\text { W.P }\end{array}$ & 66 & $\begin{array}{l}6 \\
3\end{array}$ & $\begin{array}{l}7 \\
2\end{array}$ & meningkat \\
\hline $\begin{array}{l}1 \\
5\end{array}$ & $\begin{array}{l}\text { Koma } \\
\text { ng } \\
\text { Suci } \\
\text { Cahya } \\
\text { ni }\end{array}$ & 86 & $\begin{array}{l}8 \\
0\end{array}$ & $\begin{array}{l}9 \\
0\end{array}$ & meningkat \\
\hline
\end{tabular}

\begin{tabular}{|c|c|c|c|c|c|}
\hline $\begin{array}{l}1 \\
6\end{array}$ & \begin{tabular}{|l|} 
Luh \\
Nila \\
Mahay \\
ani \\
\end{tabular} & 62 & $\begin{array}{l}7 \\
3\end{array}$ & $\begin{array}{l}7 \\
8\end{array}$ & meningkat \\
\hline $\begin{array}{l}1 \\
7\end{array}$ & $\begin{array}{l}\text { M. } \\
\text { Rafli }\end{array}$ & 74 & $\begin{array}{l}8 \\
2\end{array}$ & $\begin{array}{l}8 \\
6\end{array}$ & meningkat \\
\hline $\begin{array}{l}1 \\
8\end{array}$ & $\begin{array}{l}\text { Made } \\
\text { Endan } \\
\text { g } \\
\text { Supra } \\
\text { wan } \\
\text { Ningsi } \\
\text { h }\end{array}$ & 60 & $\begin{array}{l}7 \\
4\end{array}$ & $\begin{array}{l}7 \\
5\end{array}$ & meningkat \\
\hline $\begin{array}{l}1 \\
9\end{array}$ & $\begin{array}{l}\text { Maulid } \\
\text { ia } \\
\text { Sahar } \\
\text { ani } \\
\end{array}$ & 65 & $\begin{array}{l}8 \\
5\end{array}$ & $\begin{array}{l}9 \\
0\end{array}$ & meningkat \\
\hline $\begin{array}{l}2 \\
0\end{array}$ & $\begin{array}{l}\text { Muha } \\
\text { mmad } \\
\text { Reyna } \\
\text { ldi S }\end{array}$ & 66 & $\begin{array}{l}7 \\
0\end{array}$ & $\begin{array}{l}9 \\
0\end{array}$ & meningkat \\
\hline $\begin{array}{l}2 \\
1 \\
\end{array}$ & $\begin{array}{l}\text { Naufal } \\
\text { Ali }\end{array}$ & 64 & $\begin{array}{l}7 \\
0\end{array}$ & $\begin{array}{l}8 \\
2 \\
\end{array}$ & meningkat \\
\hline $\begin{array}{l}2 \\
2\end{array}$ & $\begin{array}{l}\mathrm{Ni} \\
\text { Koma } \\
\text { ng } \\
\text { Pitriani }\end{array}$ & 64 & $\begin{array}{l}8 \\
0\end{array}$ & $\begin{array}{l}8 \\
4\end{array}$ & meningkat \\
\hline $\begin{array}{l}2 \\
3\end{array}$ & \begin{tabular}{|l|} 
Ni Luh \\
Putu \\
Puspit \\
a Sari \\
\end{tabular} & 70 & $\begin{array}{l}77 \\
5\end{array}$ & $\begin{array}{l}8 \\
5\end{array}$ & meningkat \\
\hline $\begin{array}{l}2 \\
4\end{array}$ & $\begin{array}{l}\text { Putu } \\
\text { Elvira } \\
\text { Chalist } \\
\text { a M }\end{array}$ & 50 & $\begin{array}{l}6 \\
4\end{array}$ & $\begin{array}{l}8 \\
0\end{array}$ & meningkat \\
\hline $\begin{array}{l}2 \\
5\end{array}$ & \begin{tabular}{|l} 
Putu \\
Febry \\
Valenti \\
na \\
\end{tabular} & 60 & $\begin{array}{l}6 \\
3\end{array}$ & $\begin{array}{l}8 \\
0\end{array}$ & meningkat \\
\hline $\begin{array}{l}2 \\
6\end{array}$ & $\begin{array}{l}\text { Putu } \\
\text { Randy } \\
\text { Putra } \\
\text { Sena } \\
\end{array}$ & 60 & $\begin{array}{l}7 \\
3\end{array}$ & $\begin{array}{l}7 \\
6\end{array}$ & meningkat \\
\hline \multicolumn{6}{|c|}{$\begin{array}{l}\text { Berdasarkan tabel } 4.8 \text {, } \\
\text { ambarkan pencapaian skor } \\
\text { va pada tindakan I dan tindakan } \\
\text { terlihat pada tindakan II } \\
\text { ggalami peningkatan skor rata- } \\
\text { klasikal, yaitu } 81,8 \%\end{array}$} \\
\hline
\end{tabular}


sedangkans skor rata-rata pada siklus I 73,8\%.

Secara keseluruhan dan berdasarkan hasil rata-rata, terjadinya peningkatan dan tercapainya ketuntasan sudah melebihi KKM yang ditentukan oleh sekolah, yaitu 75 . Dengan adanya pencapaian ketuntasan tersebut, tindakan penelitian ini dapat dihentikan.

\section{PEMBAHASAN}

Berdasarkan hasil penelitian ditemukan beberapa hal untuk meningkatkan keterampilan menulis teks eksplanasi, yaitu (1) terdapat beberapa langkah penggunaan media breaking news untuk meningkatkan kemampuan dan tercapainya ketuntasan hasil belajar menulis teks eksplanasi terlihat pada (a) isi kalimat, (b) struktur kalimat, (c) penggunaan bahasa, dan (d) pengembangan kalimat,

kemampuan dan ketuntasan hasil belajar menulis teks eksplanasi pada siswa kelas VIII SMP Mutiara Singaraja dengan menggunakan media video breaking news, serta (3) respons siswa positif terhadap penggunaan media video breaking news. Temuan-temuan tersebut diuraikan sebagai berikut.

Temuan pertama, dalam proses pembelajaran menulis teks eksplanasi menggunakan media video breaking news, ada beberapa langkah yang harus dilalui agar keterampilan menulis teks eksplanasi siswa bisa meningkat. Adapun beberapa langkah utama yang harus ditempuh oleh peneliti dan guru dalam penggunaan media video breaking news sebagai media untuk meningkatkan keterampilan menulis siswa kelas VIII SMP Mutiara Singaraja, antara lain (1) kegiatan awal, (2) inti, dan (3) kegiatan akhir atau penutup. Pada siklus I, masih ditemukan kekurangan pada langkah-langkah pembelajaran menulis teks eksplanasi. Untuk mengantisipasi kekurangan tersebut, dilakukanlah perbaikan serta penambahan langkah-langkah pembelajaran pada siklus II. Penambahan langkahlangkah pembelajaran pada siklus II tersebut antara lain, (1) pemberian struktur teks eksplanasi, pemberian ejaan, dan (3) pemberian contoh teks eksplanasi.

Temuan kedua menyangkut peningkatan kemampuan menulis teks eksplanasi siswa dengan menggunakan media video breaking news. Penggunaan media video breaking news terbukti dapat meningkatkan kinerja siswa dalam menulis teks eksplanasi. Hal ini dapat terlihat dari hasil penelitian. Hasl penelitian menunjukkan terjadi peningkatan kemampuan menulis teks eksplanasi pada siklus I adalah 1919 dengan rata-rata 73.8\%, sedangkan pada siklus II mendapat total skor berjumlah 2127 dengan rata-rata $81.8 \%$. Peningkatan yang terjadi sebesar $2,43 \%$.

Dalam hal ini, guru Bahasa Indonesia di Kelas VIII SMP Mutiara Singaraja sudah menerapkan media video breaking newsdengan baik pada saat pembelajaran teks eksplanasi.

Temuan ketiga, yaitu siswa memberikan respons positif terhadap penggunaan media video breaking news saat pembelajaran berlangsung. Siswa menjadi senang dan aktif mengikuti pembelajaran menulis teks eksplansi dengan menggunakan media video breaking news. Tidak hanya merasa senang dan aktif, tetapi dengan menggunakan media video breaking news tersebut siswa lebih terlihat antusias serta lebih terlihat kreatif dalam pembelajaran, khususnya 
pembelajaran menulis teks eksplanasi. Siswa tidak ada lagi yang terlihat bosan dan ragu dalam proses pembelajaran menulis teks eksplanasi. Siswa yang awalnya kurang bersemangat dalam pembelajaran, kini sudah bersemangat. Hal ini dikarenakan guru mampu mengemas pembelajaran dengan menarik. Cara belajar yang diterapkan mampu memotivasi siswa dalam belajar. Penggunaan media video breaking news dapat menciptakan suasana belajar yang lebih menyenangkan dengan mengajak siswa secara langsung contoh-contoh hal yang diamati pada video. Siswa juga merasa senang karena memperoleh pengalaman belajar yang lebih menarik. Rasa senang, aktif, antusias, dan kreatif tersebut dapat dilihat dari rata-rata respons siswa yang positif. Respons siswa terus meningkat. Pada siklus I, respons siswa memperoleh rata-rata sebesar $41,46 \%$. 5 siswa dengan persentase $19,23 \%$ memiliki respons siswa sangat positif, 20 siswa dengan persentase $76,93 \%$ memiliki respons positif, 1 siswa dengan persentase $3.45 \%$ memiliki respons cukup positif, dan tidak ada yang memiliki respons kurang positif dan sangat kurang positif. Pada siklus II, respons siswa 42,07\%, 7 siswa dengan persentase $26,69 \%$ memiliki respons sangat positif, dan 19 siswa dengan persentase $73,03 \%$ memiliki respons positif. Tidak ada yang memiliki respons cukup positif, kurang positif, dan sangat kurang positif. Walaupun respons siswa dari sikus I dan siklus II mengalami peningkatan, kategori yang dicapai tetap sama, yakni aktif. Respons positif yang ditunjukkan siswa dapat diamati dari keantusiasan siswa dalam kegiatan pembelajaran.
Maka dari itu, penggunaan media video breaking news sebagai media pembelajaran dapat meningkatkan keterampilan menulis teks eksplanasi siswa. Hal ini dapat dilihat dari peningkatan hasil tes keterampilan menulis pada siklus II dibandingkan dengan hasil tes pada siklus I dan peningkatan hasil belajar dapat pula dilihat dari perbandingan nilai awal siswa sebelum melaksanakan tindakan terhadap siklus I. Aktivitas belajar siswa juga mengalami peningkatan yang terlihat pada siklus I dan siklus II. Untuk mengatasi beragam masalah yang ditemukan oleh peneliti ataupun siswa dalam pembelajaran, pembelajaran dengan penggunaan media video breaking news dapat dijadikan sebagai salah satu alternatif dalam upaya meningkatkan keterampilan menulis teks eksplanasi siswa.

\section{PENUTUP}

Pelaksanaan tindakan dalam penelitian tindakan kelas ini dilaksanakan dalam dua siklus atau dikenal dengan multisiklus. Dari hasil pembahasan pada bab IV, dapat disimpulkan sebagai berikut. Yang pertama, Proses pembelajaran siswa kelas VIII SMP Mutiara Singaraja dengan menggunakan media video breaking news sebagai media pembelajaran lebih baik dibandingkan saat pembelajaran tanpa menerapkan media pembelajaran media video breaking news.

Yang kedua, Penggunaan media video breaking news sebagai media pembelajaran dapat meningkatkan keterampilan menulis teks eksplanasi di kelas VIII SMP Mutiara Singaraja. Peningkatan tersebut terlihat dari pemerolehan skor tes menulis teks eksplanasi siswa pada siklus I dan II yang 
mengalami peningkatan dan mencapai KKM, yaitu 75. Pada setiap tahap pembelajaran skor siswa selalu mengalami penigkatan, baik dari pratindakan, siklus I, dan siklus II. Pada saat refleksi awal, yaitu dalam pratindakan skor ratarata yang diperoleh siswa adalah 65,02 (kategori cukup). Saat siklus I, skor rata-rata siswa meningkat menjadi 73,8 (kategori baik). Namun, pada siklus II, skor rata-rata yang diperoleh siswa meningkat menjadi 81,8 (kategori baik). Jika dibandingkan dengan pencapaian peningkatan kemampuan menulis antara pratindakan dan siklus II, skor rata-rata sudah memenuhi standar ketuntasan. Jika dilihat dari segi ketuntasan belajar. Pembelajaran pada siklus II ini sudah dapat dikatakan tuntas karena dari 26 siswa, hanya satu siswa saja yang mendapat nilai masih di bawah KKM. Sedangkan yang lainnya sudah memenuhi standar yang telah ditetapkan.

Yang ketiga, Siswa memberikan respons yang positif terhadap penggunaan media video breaking news di televisi untuk meningkatkan kemampuan menulis teks eksplanasi. Siswa sangat antusias dan merasa senang saat pembelajaran berlangsung. Siswa juga menjadi lebih mudah memahami materi teks eksplanasi. Namun pada siklus ke II respons siswa sangat positif. Hal ini terbukti berdasarkan pendapat siswa yang mengatakan sangat bersemangat dalam mengikuti pembelajaran.

Berdasarkan

pemaparan

mengenai hasil penelitian dan simpulan, terdapat tiga saran yang dapat disampaikan pada penelitian ini. Pertama, dalam pembelajaran menulis, khususnya menulis teks eksplanasi, guru hendaknya menggunakan media video breaking news.

Kedua, dalam pembelajaran bahasa Indonesia, besar harapan peneliti agar media video breaking news yang digunakan pada keterampilan menulis, sebab dalam proses pengajarannya, siswa akan mendapat pengalaman yang berbeda. Siswa akan mendapat pengetahuan baru dalam menulis teks eksplanasi dengan menggunakan media video breking news sebagai media pembelajaran.

Ketiga, Peneliti mengharapkan peneliti lain untuk mengadakan penelitian lanjutan yang sejenis dengan penelitian ini sehingga diperoleh hasil yang lebih meyakinkan serta dapat memberikan sumbangan bagi guru untuk bahan kajian dan peningkatan mutu pendidikan. Dari hal tersebut, maka peneliti berharap peneliti lain agar menemukan kembali suatu solusi yang tepat agar kegiatan menulis tersebut benar-benar didasarkan kejujuran atas kemampuan yang dimiliki oleh masing-masing siswa dalam menulis.

\section{DAFTAR PUSTAKA}

Arsyad, Azhar. (2010). Media Pembelajaran. Jakarta: PT Raja Grafindo Persada.

Prihantini, Ainia. (2015). Master Bahasa Indonesia. Jogyakarta: PT Bentang Pustaka.

Sadiman, Arief S dkk. (2006). Media Pendidikan Pengertian, Pengembangan dan Pemanfaatannya. Jakarta: PT Raja Grafindo Persada.

Santana, Septiawan. (2007). Menulis itu lbarat Ngomong. Bandung: Kawan Pustaka.

Sutisno, P.C.S. (1993). Pedoman Praktis Penulisan Skenario 
e-Journal Jurusan Pendidikan Bahasa dan Sastra Indonesia

Volume : 9 Nomor: 2, Agustus 2019

P-ISSN : 2614-4743 (cetak) dan e-ISSN : 2614-2007 (online)

Televisi dan Video. Jakarta:

PT. Grasindo.

Tarigan. (1994). Menulis Suatu

Keterampilan Suatu Bahasa.

Bandung: Angkasa. 